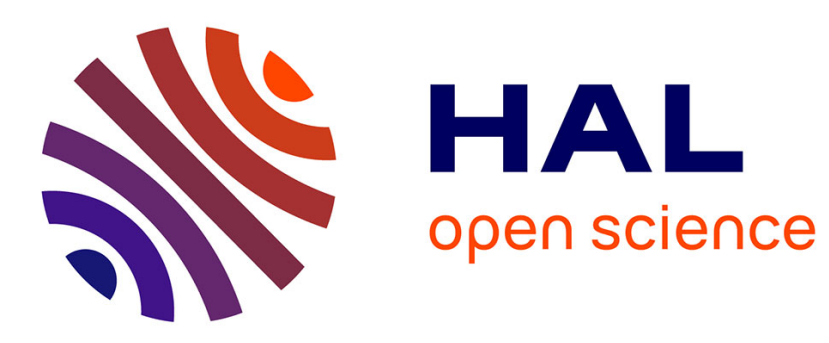

\title{
Impact of Personality Traits (BFI-2-XS) on Use of Shared Online Calendars
}

Petr Doucek, Antonin Pavlicek, Frantisek Sudzina

\section{To cite this version:}

Petr Doucek, Antonin Pavlicek, Frantisek Sudzina. Impact of Personality Traits (BFI-2-XS) on Use of Shared Online Calendars. 13th International Conference on Research and Practical Issues of Enterprise Information Systems (CONFENIS), Dec 2019, Prague, Czech Republic. pp.123-127, 10.1007/978-3030-37632-1_11. hal-03408416

\section{HAL Id: hal-03408416 https://hal.inria.fr/hal-03408416}

Submitted on 29 Oct 2021

HAL is a multi-disciplinary open access archive for the deposit and dissemination of scientific research documents, whether they are published or not. The documents may come from teaching and research institutions in France or abroad, or from public or private research centers.
L'archive ouverte pluridisciplinaire HAL, est destinée au dépôt et à la diffusion de documents scientifiques de niveau recherche, publiés ou non, émanant des établissements d'enseignement et de recherche français ou étrangers, des laboratoires publics ou privés. 


\title{
Impact of Personality Traits (BFI-2-XS) on Use of Shared Online Calendars
}

\author{
Petr Doucek ${ }^{1[0000-0002-5647-661 X]}$, Antonin Pavlicek ${ }^{1[0000-0002-1230-5982]}$ and Frantisek Sudzi- \\ na $^{1,2[0000-0003-1867-9237]}$ \\ ${ }^{1}$ University of Economics, Nám. W. Churchilla 4, 13067 Prague, Czech Republic \\ ${ }^{2}$ Aalborg University, A. C. Meyers Vænge 15, 2450 Copenhagen, Denmark \\ sudzina@business.aau.dk
}

\begin{abstract}
People use calendars for a long time but stand-alone electronic calendars came along only with personal computers, while shared online calendars are here only for less than two decades. The paper investigates impact of personality (following the Big Five Inventory framework) on use of shared online calendars. Data were gathered in the Czech Republic. The sample consisted of university students. Age, gender, and type of student job were used as control variables. With regards to the results, gender, openness to (cognitive) experience, and type of student job influence the adoption. It is male, more open to experience, and working student who use shared online calendars more.
\end{abstract}

Keywords: Personality Traits, Calendar, Adoption.

\section{Introduction}

Shared online calendars belong to group support software [1]. History of shared online calendars is described in a greater detail in [2]. They ought to enable better collaboration through the possibility of collective use of individual calendars between multiple users [3]. Shared online calendars are useful for scheduling shifts, communicating opening/working hours, their changes, staff vacation and sick days [4]. The issue is that scheduling per se "is often iterative and requires a great amount of coordination" [5]. Calendars are also shared in order to coordinate appointments [6].

When shared with others, calendars provide information about the owner of the calendar. Users tend to have more than one shared calendar in order to manage who has access to what information [6]. Users that used a combination of desktop and mobile calendars perceived much higher effectiveness and satisfaction compared to ones who used only one software tool or a paper-based calendar [7].

On some occasions, it is a bottom-up process - when an organization does not offer it, employees adopt a tool that suits them. [8] describe a case of adoption of a shared online calendar by a mid-level manager in one of a supermarket store in Denmark. Though it was not appreciated by their IT department, most likely for security and governance reasons. It could be considered a case of Bring Your Own Device 
(BYOD). Although it was not the company's policy in this particular supermarket chain, many companies adopt BOYD in the effort to be more agile and up-to-date.

It appears that there exists no research linking use of shared online calendars to personality traits. In order to close the gap, this paper investigates impact of personality traits on use of shared online calendars, while controlling for age, gender, and job type.

\section{Data and Methodology}

Data were collected using an on-line questionnaire in from December 2017 to March 2018. Surveyed were university students from the Czech Republic. The sample consisted of 478 respondents (272 male, 206 female; 20.5 years old on average), of whom 189 respondents indicated that they use shared online calendars. As for their experience from practice, 12 have a full time within the field of study, 16 have a full time outside the field of study, 164 have a part-time job, 176 have a temporary job (brigade), and 106 only study.

Personalities were evaluated according to John and Soto's Big Five Inventory-2 [9] using a validated Czech translation by Hřebíčková et al. [10]. For this conference paper, only BFI-2-XS [11], i.e. a 15-item version of the instrument was used. The instrument uses a 1-5 Likert scale where 1 means strongly disagree and 5 means strongly agree.

The question for the explanatory variable was "Do you use the following services? Shared online calendars (like Google Calendar)" Possible answers were:

- "No" (coded as 0),

- "Yes, sometimes" (coded as 1),

- "Yes, often" (coded as 2).

Also additional questions were included in the questionnaire but they have not been analyzed in this paper.

Ordinal logistic regression will be used to test influence of age, gender, job type and five personality traits on use of shared online calendars. A multivariate approach will be used. Calculations will be done in SPSS.

\section{Results}

The research question is if any/which of five personality traits influence use of shared online calendars, while controlling for age, gender, and job type. Ordinal logistic regression estimates for the full model are in Table 1 . The model per se is significant, $\mathrm{p}$-value $<.001$, Cox and Snell pseudo- $\mathrm{R}^{2}$ is .126 , Nagelkerke pseudo- $\mathrm{R}^{2}$ is .148 , and McFadden pseudo- $\mathrm{R}^{2}$ is .071 .

Table 1. Full model - ordinal regression.

\begin{tabular}{llllll}
\hline & Estimate & Std. Error & Wald & df & Sig. \\
\hline [calendar $=.00]$ & 3.079 & 1.303 & 5.586 & 1 & .018
\end{tabular}




\begin{tabular}{llllll} 
[calendar = 1.00] & 4.111 & 1.309 & 9.860 & 1 & .002 \\
Extraversion & .153 & .123 & 1.545 & 1 & .214 \\
Agreeableness & -.262 & .140 & 3.484 & 1 & .062 \\
Conscientiousness & -.056 & .143 & .155 & 1 & .693 \\
Neuroticism & .043 & .114 & .140 & 1 & .709 \\
Openness to experience & .257 & .127 & 4.125 & 1 & .042 \\
Age & .053 & .047 & 1.254 & 1 & .263 \\
Gender = male & .701 & .208 & 11.333 & 1 & .001 \\
Gender = female & $0 \mathrm{a}$ &. &. & 0 &. \\
Job type = full time within the & 1.892 & .612 & 9.568 & 1 & .002 \\
field of study & & & & & \\
Job type = full time outside & .604 & .556 & 1.180 & 1 & .277 \\
the field of study & & & & & \\
Job type = part-time job & 1.351 & .294 & 21.102 & 1 & .000 \\
Job type = temporary job & .594 & .290 & 4.211 & 1 & .040 \\
Job type = only study & $0 \mathrm{a}$ &. &. & 0 &. \\
\hline
\end{tabular}

Legend: a. This parameter is set to zero because it is redundant.

Students who are (less agreeable,) more open to experience, men, and working are more likely to use shared online calendars. Ordinal logistic regression estimates for the streamlined model are in Table 2. The model per se is significant, p-value $<.001$, Cox and Snell pseudo- $\mathrm{R}^{2}$ is .123 , Nagelkerke pseudo- $\mathrm{R}^{2}$ is .144 , and McFadden pseudo- $\mathrm{R}^{2}$ is .069 .

Table 2. Streamlined model - ordinal regression.

\begin{tabular}{llllll}
\hline & Estimate & Std. Error & Wald & df & Sig. \\
\hline [calendar $=.00$ ] & 1.851 & .655 & 7.997 & 1 & .005 \\
[calendar = 1.00] & 2.872 & .662 & 18.788 & 1 & .000 \\
Agreeableness & -.252 & .136 & 3.447 & 1 & .063 \\
Openness to experience & .290 & .125 & 5.429 & 1 & .020 \\
Gender = male & .730 & .199 & 13.410 & 1 & .000 \\
Gender = female & $0 \mathrm{a}$ &. &. & 0 &. \\
Job type = full time within the & 2.040 & .601 & 11.537 & 1 & .001 \\
field of study & & & & & \\
Job type = full time outside & .768 & .541 & 2.015 & 1 & .156 \\
the field of study & & & & & \\
Job type = part-time job & 1.507 & .280 & 28.920 & 1 & .000 \\
Job type = temporary job & .694 & .285 & 5.941 & 1 & .015 \\
Job type = only study & $0 \mathrm{a}$ &. &. & 0 &. \\
\hline
\end{tabular}


Legend: a. This parameter is set to zero because it is redundant.

The estimates stay almost the same if agreeableness is removed from the model. It is not clear whether agreeableness should be included in the model as it is not clear why more agreeable respondents would use shared calendars less. On the other hand, a short scale was used, i.e. it may be less precise, so p-value of .063 should not automatically mean that agreeableness does not influence use of shared online calendars; in case the trait is measured using a longer scale, the p-value may be lower.

It also cannot be completely ruled out students who work time outside the field of study are using shared online calendars more often than students who only study because it is based only on a relatively small sample (16 respondents). If the standard deviation for the full-time job outside the field of study was like the ones for a parttime or a temporary job, the p-value would be below .05 .

\section{Conclusions}

To sum up, respondents who are more open to experience, men, and working alongside studies are more likely to use shared online calendars. Since virtually all respondents were digital natives, it is not surprising that age was not found to be significant. So, in the future research, which will be aimed at the population of all employed people, age should be included (as a control variable) in spite of not being significant in this particular research.

More research will be needed, esp. with regards to agreeableness - whether it or any of its facets influences use of shared online calendars if it is measured using a longer scale. But more research will be needed also with regards to openness to experience as it is unclear whether people open experience use shared online calendars more because it is a new technology and they are more open to try it, or they are involved in more activities, so they actually have a higher need for coordination.

\section{Acknowledgment}

Paper was processed with contribution of grant IGS 27/2019 from the Faculty of Informatics and Statistics, University of Economics, Prague.

\section{References}

1. Palen, L., Grudin, J.: Discretionary adoption of group support software: Lessons from calendar applications. In: Implementing collaboration technologies in industry, pp. 159-180. Springer, London (2003).

2. Lord, C.: Evolution of the electronic calendar: introducing social calendaring, http://citeseerx.ist.psu.edu/viewdoc/download?doi=10.1.1.510.2442\&rep=rep1\&type=pdf, last accessed 2019/8/31.

3. van den Hooff, B.: Electronic coordination and collective action: Use and effects of electronic calendaring and scheduling. Information \& Management 42(1), 103-114 (2004). 
4. Hughes, S.E.: Scheduling Using a Web-Based Calendar: How Teamup Enhances Communication. Public Services Quarterly, 14(4), pp.362-372 (2018).

5. Lewejohann, L.: Fill My Datebook: A software tool to generate and handle lists of events. Behavior Research Methods 40(2), 391-393 (2008).

6. Thayer, A., Bietz, M. J., Derthick, K., Lee. C. P.: I Love You, Let's Share Calendars: Calendar Sharing As Relationship Work. In: Proceedings of the ACM 2012 Conference on Computer Supported Cooperative Work (CSCW '12). ACM, New York, pp. 749-758 (2012).

7. Wu, D.: Identifying Usability Issues in Personal Calendar Tools. In International Conference on Networked Digital Technologies, pp. 136-146. Springer, Berlin, Heidelberg (2011).

8. Kerr, D., Talaei-Khoei, A., Ghapanchi, A. H.: A paradigm shift for bring your own device (BYOD)." In: Twenty-fourth Americas Conference on Information Systems, AIS, New Orleans (2018).

9. Soto, C. J., John, O. P.: The next Big Five Inventory (BFI-2): Developing and assessing a hierarchical model with 15 facets to enhance bandwidth, fidelity, and predictive power. Journal of Personality and Social Psychology 113, 117-143 (2017).

10. Hrebicková, M. et al.: Big Five Inventory 2: Hierarchický model s 15 subškálami. Ceskoslovenska Psychologie (2019).

11. Soto, C., P. John, O.: Short and Extra-Short Forms of the Big Five Inventory-2: The BFI2-S and BFI-2-XS. Journal of Research in Personality 68, 69-81 (2017). 